\title{
WATER REPELLENCY BY LABORATORY BURNING \\ OF FOUR NORTHERN ROCKY MOUNTAIN FOREST SOILS
}

\author{
P. R. Robichaud* and R. D. Hungerford ${ }^{1}$ \\ USDA-Forest Service, Rocky Mountain Research Station \\ Moscow, Idaho and Missoula, Montana, USA
}

\begin{abstract}
Highly variable water repellent soil conditions have been reported after forest fires. We examined interactions among heating, soil water content and soil texture on water repellency. Undisturbed, 305-mm diameter cores were collected in the field from four soils commonly referred to as ash-cap, mixed ash-cap, no ash-cap and granitic soils. Three artificial burning treatments and a control (no heat) and two soil water contents were evaluated under laboratory conditions. Twenty water drops were placed on each soil layer starting at the surface and continuing at 10-mm intervals to a depth of $70-\mathrm{mm}$; and the times to infiltrate were recorded. The dry control treatment was more water repellent than the wet control treatment. The dry, low heat treatment was the most repellent, 10 to 20 -mm below the soil surface with mean water drop penetration times greater that $60 \mathrm{~s}$. Repellency decreased as the heating increased. In wet soils of the high heat treatment, a water repellent layer was generally detected 30 to 50-mm below the soil surface. Presumably, hydrophobic substances were translocated along the temperature gradient which cooled at depth $(<50 \mathrm{~mm})$ causing condensation on the soil particles. Water repellency after prescribed fire would probably be minimal because long heating times are not common.
\end{abstract}

Keywords: hydrophobicity, soil heating, water drop penetration time, water repellent.

\footnotetext{
$1_{*}$ Corresponding author. USDA-Forest Service, Rocky Mountain Research Station, Forestry Science Laboratory, 1221 South Main St., Moscow, ID 83843, USA, probi@forest.moscowfsl.wsu.edu; and USDA-Forest Service, Rocky Mountain Research Station, Intermountain Fire Sciences Laboratory, P.0. Box 889, Missoula, MT 59807, USA.
} 


\section{Introduction}

When water is applied to most coarse-textured soils, it will readily penetrate and infiltrate. But in water repellent soil, this rapid penetration does not occur. The length of time a water droplet remains on the soil surface before absorbtion depends upon the degree of water repellency (DeBano et al., 1967) which is dependent on the attractive forces between water and the soil surface.

There are several ways that soils can become water repellent. Drying of organic matter can induce water repellency, mainly in the surface layers of peat soil which are difficult to re-wet after drying. Organic substances leached from plant litter and produced by microbial mycelium can induce repellency (Hudson et al., 1994; DeBano et al., 1998). Extreme drying of mineral soil will result in water repellency also. Mineral particles need not be individually coated with hydrophobic substances; merely intermixing mineral soil particles with organic matter may induce severe water repellency (DeBano, 1981; Giovannini and Lucchesi, 1983). Sandy soils have smaller specific surface areas than fine-textured soils and therefore are more likely to be coated by the same amount of hydrophobic substance. Finally, heating organically coated particles or intermixed soil can markedly increase water repellency (DeBano et al., 1976).

Combustion of surface fuels and the forest floor (during a severe burn), vaporizes hydrophobic organic substances which move downwards and condense at cooler underlying soil layers (DeBano, 1966; 1981; DeBano et al., 1998). DeBano and Krammes (1966) found that water repellency was dependent on the heating temperatures. Heating for $20 \mathrm{~min}$ to $260{ }^{\circ} \mathrm{C}$ produced an extremely water repellent condition, but heating to 370 ${ }^{\circ} \mathrm{C}$ for $20 \mathrm{~min}$ started to reduce water repellency. Fire induced soil surface temperatures may reach $845{ }^{\circ} \mathrm{C}$ (Dunn and DeBano, 1977), but the temperature gradient is steep and temperatures decrease rapidly with depth, because dry soil is a poor conductor of heat. At 50-mm depth, the temperature is not likely to exceed $150{ }^{\circ} \mathrm{C}$ (DeBano et al., 1977) except with long heating times that occur during smoldering fires.

Savage (1974) concluded that the movement of hydrophobic substances from the forest floor occurred mainly when the fire was actively burning. After burning, heat, moving downward through the underlying sandy soil, mixed and re-volatilized some of the hydrophobic substances, thereby broadening the water repellent layer. The temperature needed to fix and re-volatilize the substances was greater than $250^{\circ} \mathrm{C}$. Intense water repellency is formed when soils containing hydrophobic substances are heated to temperatures between 175 and $205^{\circ} \mathrm{C}$ (DeBano, 1981). Several studies show that the substances responsible for water repellency were destroyed when soils were heated above $290{ }^{\circ} \mathrm{C}$ (DeBano et al., 1976; Savage, 1974). 
The objective of this study was to determine the effects of heat treatment, soil moisture and soil texture on water repellency in a laboratory experiment that simulated heat transfer from the soil surface into the soil profile with undisturbed soil cores. The soils were selected based on management concerns about fire induced water repellency. Our three general hypotheses were: 1) fire severity (heat treatment) affects water repellency; 2) soil water content (moisture condition) affects soil heating and subsequent water repellency; 3 ) and soil textural properties affect fire-induced water repellency.

To test the effects of heat treatment in the soil profile we hypothesized that: 1) when temperatures in a given layer are between 150 and $205^{\circ} \mathrm{C}$, hydrophobic substances are volatilized and will be available to condense and create water repellency in that layer; 2) when temperatures in a given layer are between 205 and $260{ }^{\circ} \mathrm{C}$, water repellency may occur in that layer and the underlying layer; and 3) when temperatures in a layer are greater than $260{ }^{\circ} \mathrm{C}$, then water repellency is destroyed and the volatilized substances condense in the underlying layers where temperatures are less than $260^{\circ} \mathrm{C}$. We recognized that heating soils in an oven (DeBano, 1981; DeBano and Krammes, 1966) does not address the movement of hydrophobic substances into the soil profile, therefore heat treatments were applied at the surface.

To examine the effects of moisture condition, we also hypothesized that when soils are wet, temperatures will be lower deeper in the soil profile; thus, depth of repellency will be reduced compared to dry soils. We further hypothesized that coarse-textured soils with lower specific surface area will have a greater tendency for repellency.

\section{Materials and Methods}

\subsection{Sample Locations}

Samples were collected in central and northern Idaho from four soils where fire induced water repellency has been observed. Three of the sites are $4 \mathrm{~km}$ north of Syringa, Idaho on the Clearwater National Forest $\left(\mathrm{N} 45^{\circ} 16^{\prime}, \mathrm{W} 115^{\circ} 43^{\prime}\right.$, elev. $\left.1130 \mathrm{~m}\right)$ and the other site is $42 \mathrm{~km}$ east of McCall, Idaho on the Payette National Forest $\left(\mathrm{N} 45^{\circ} 04^{\prime}, \mathrm{W} 115^{\circ} 44^{\prime}\right.$, elev. $\left.1520 \mathrm{~m}\right)$. The soils near Syringa are Belt series metamorphic rockderived soils. The ash-cap soil (Table 1) has a high component of volcanic ash, thought to have come from the eruption of Mt. Mazama, and the habitat type is grand fir/wild ginger (Abies grandis/Asarum caudatum) (Cooper et al., 1987). The mixed ash-cap soil has a reduced component of volcanic ash and the habitat type is grand fir/queencup beadlily (Abies grandis/Clinatonia uniflora). Volcanic ash is absent in the no ash-cap soil and the habitat type is western red cedar/maidenhair fern (Thuja plicata/Adiantum pedatum). The granitic soil is 
derived granitic rock (Idaho batholith), and the habitat type is Douglas fir/white spiraea (Pseudotsuga/Menziesii) (Steele et al., 1981). Pertinent soil characteristics, based on samples from the control (unburned) soil cores used in the experiment, are listed in Table 1. Total nitrogen (N) and total carbon (C) were analyzed using a PerkinElmer $2400 \mathrm{CHN}$ analyzer.

A sampler was fabricated to remove soil columns, including the forest floor layers (Oi and Oa horizons), with as little disturbance as possible. A 305-mm diameter, 305-mm deep steel sampler that was sharpened at the bottom was driven into the soil with a 9-kg sliding hammer. The sampler was driven into the soil to a 300-mm depth, usually within the B horizon. The lid was attached and the sampler was twisted approximately $90^{\circ}$ to break the soil column at the bottom of the sampler. The sampler was lifted out of the ground and a bottom plate attached for transport. If large woody debris was encountered, the sampling location was moved approximately $0.5 \mathrm{~m}$. Twenty samples were randomly located within a $500-\mathrm{m}^{2}$ area at each site. In the laboratory, samples were transferred to cardboard cylinders for storage. The soil cores were insulated with a 25-mm thick ceramic blanket before heating.

\subsection{Treatments}

Samples for each of the four soils were burned in the laboratory at one of two soil water contents $(\leq 15$ and $\geq 20$ percent by weight) and four heat treatments: control (C)-no heating; low (L)-100 to $150{ }^{\circ} \mathrm{C}$; moderate (M)-250 to $300{ }^{\circ} \mathrm{C}$; and high (H)-400 to $500^{\circ} \mathrm{C}$. Measured temperatures in the 0 to 10 -mm soil layer were used to check the assigned heat treatment and make adjustments in the final assignments of heat treatments. Heat treatments represented soil temperatures that have been reported under prescribed fires and wildfires (Wells et al., 1979). A factorial experiment of four heat treatments, four soils and two moisture conditions was duplicated. Treatments were assigned randomly to the soil cores from each site.

\subsection{Sample Preparation}

In the laboratory, each sample was either wetted or allowed to air dry to the desired soil water content. Soil cores were wetted by drip irrigation. Soil water contents were periodically measured with time domain reflectometry (TDR) soil moisture probes (Topp et al., 1982).

Thermocouples were placed at 16 depths: surface, within the forest floor, forest floor-mineral soil interface, and at 5, 15, 25, 40,60, and 80-mm and at 20-mm intervals below this on opposite sides of the cores 
(duplicated for each depth). They were installed horizontally from the side of the cores using a reference frame to keep them parallel to the surface and to maintain proper depths. The sensing end of the thermocouple was located about 100 to 120-mm from the outside edge of the core. Temperatures were recorded at 30-s intervals.

A radiant propane heater was located directly above the surface. Heat was applied until the desired temperatures were obtained. It took several hours for the high heat treatments to be reached. After the forest floor ignited, it generally burned for several hours.

Soil water contents were chosen to provide two moisture conditions that are typical in the spring and late summer/fall in the Northwest when prescribed fires and wildfires occur. Soil water contents of the cores were assigned dry ( $\leq 15$ percent water content) or wet ( $\geq 20$ percent water content) moisture conditions based on the TDR readings, and adjusted based on post-burn gravimetric soil water content from the lower depths. The soil water content for the dry moisture condition ranged from 5 to 15 percent except for some of the control cores which were less than 5 percent. The wet moisture condition ranged from 25 to 40 percent except for some of the control cores which had soil water contents greater than 40 percent.

\subsection{Post-burn Sampling}

Ash depth, actual thermocouple depth relative to the soil surface, and degree of water repellency were measured. Gravimetric soil water content samples were also taken at 0, 10, 20, 30, 50 and 70-mm depths. The water drop penetration time (WDPT) method (DeBano, 1981) was used to determine water repellency starting at the surface of the ash, then the forest floor-mineral soil interface and continuing with each 10 -mm layer as it was uncovered to the $30-\mathrm{mm}$ layer, then at 20 -mm intervals to $70-\mathrm{mm}$. A wire screen $(5$ by 5 $\mathrm{mm}$ mesh) was randomly oriented on each layer. An eye-dropper was used to place 20 water drops per layer in color-coded, randomly selected squares. The time of drop penetration was determined when a droplet no longer rested on the surface in a spherical state, but infiltrated (Krammes and DeBano, 1965). The maximum time recorded was limited to $180 \mathrm{~s}$. This time limit was chosen to make reasonable estimations possible and is consistent with the methods of Krammes and DeBano (1965) and Letey et al. (1962).

\subsection{Analysis Methods}

The type IV sum of squares method was used to evaluate mean comparisons (Milliken and Johnson, 1984). This approach tests meaningful hypotheses about the means observed in the cells of the design. The assumptions for this method were met. The soils (ash-cap, mixed ash-cap, no ash-cap, granitic) were analyzed 
separately. Specific tests include comparing WDPT means between heat treatments (C-control (no heat), L-low, M-moderate, H-high), soils (ash-cap, mixed ash-cap and no ash-cap and granitic), soil moisture conditions (dry and wet) and specific interactions. The Fisher's protected Least Significant Difference (LSD) (Ott, 1988) was used for preplanned comparisons by separating the soil into two moisture conditions and testing the mean differences between heat treatments. The analysis was performed on each soil layer (depth) that was used for the WDPT test. WDPT were analyzed to a depth of 70-mm because, for the majority of the cores, little repellency occurred below this depth.

At the forest floor-mineral soil interface, the material present during the WDPT test was often a mixture of organic material and mineral soil, thus further classification was necessary. Organic material consisted of: ash, residue remaining after burning; humus, unburned-unrecognizable organic material; and litter, remaining unburned recognizable organic material. At a depth of 0-mm, a comparison of the WDPT means was conducted with organic material and mineral soil combined. Therefore at the forest floor-mineral soil interface, the WDPT is probably a function of the water drop resting on some organic material and not necessarily coating of the soil particles. For depths greater than 0-mm, no ash was present; therefore we hypothesize that the WDPT represents coating of the soil particles.

A classification scheme of 0 to 5 s-not repellent, 5 to 60 s-slightly repellent, 60 to 180 s-moderately repellent, and greater than $180 \mathrm{~s}$-extremely repellent was initially used. This classification scheme is consistent with Dekker and Ritsema (1994) except that the maximum time was limited to $180 \mathrm{~s}$ as compared to $5 \mathrm{~h}$ in their studies of naturally-occurring water repellent soils.

\section{Results and Discussion}

There were no significant differences in forest floor thickness (Oi and $\mathrm{Oa}$ ) among soils prior to treatment (Table 1). Therefore, we assumed no effect from forest floor thickness between soil cores. Total $\mathrm{N}$ and total $\mathrm{C}$ within the forest floor layer were not significantly different between soils. Within the 0 to 50 -mm layer of mineral soil, the no ash-cap soil had significantly higher total $\mathrm{N}$ and total $\mathrm{C}$ than the other soils (Table 1 ). Total $\mathrm{N}$ was not different between the other soils, but total $\mathrm{C}$ was lower for the granitic soil compared to the mixed ash-cap soil.

It was difficult to achieve uniform heating of the soil cores, because of variable forest floor consumption by burning. Because the relationship between WDPT and treatment effect may have been masked by differential heating, data from cores that had temperature variation (i.e., maximum temperatures of greater than $50{ }^{\circ} \mathrm{C}$ in the 
0 to 10 -mm soil depths from one side to another,) were not included and were considered missing values for this analysis.

The unheated control cores had greater WDPT's at most depths than any of the heat treatments (Table 2 and 3). These WDPT's indicate that the pre-treatment conditions for the dry cores were somewhat repellent and influenced the response to heating. This naturally-occurring repellency is typical of dry soils (DeBano, 1973; Dekker and Ritsema, 1994). The mixed ash-cap soil was the only soil to appear repellent in the wet, no heat moisture condition. Soil physical and chemical characteristics that we measured do not suggest an explanation.

Using the repellency scheme (Dekker and Ritsema, 1994) (Table 2), the low heat treatment had more occurrences of slightly and moderately repellent conditions than the high heat treatment. The coarse granitic soil was repellent more often than the fine ash-cap soil. To make meaningful interpretations of these classifications, further analysis was warranted by partitioning by depth and analyzing mean WDPT. Mean WDPT's were compared in a two-way and one-way analysis of variance. The results are partitioned by heating, soil and moisture condition effects.

\subsection{Temperature and Heat}

The average maximum temperatures measured are shown in Figs. 1 and 2. Three heat treatments and target temperatures within the 0 to 10-mm layer were achieved. The observed temperature gradients established by these heat treatments were typical of other reports (Campbell et al., 1995; Albini et al., 1996; DeBano et al., 1970). These gradients are explained by a linked-transport model that simultaneously computes changes in temperature and soil water content (Campbell et al., 1995). Where heating is sufficient, the temperature at each depth rises to a value approaching the boiling point of water and remains there until that layer is almost completely dry, then a rapid temperature increase occurs. Campbell et al. (1995) described the lag time in temperature increase due to soil water, and noted that temperatures close to the surface increase more quickly for dry soils, but heat transfer to lower depths is slower for dry soils than for wet soils. The damping effect of soil water content on maximum temperatures with depth is shown by steeper temperature gradients for the wet moisture condition than the dry moisture condition (Figs. 1 and 2).

An ANOVA for the dry and wet moisture conditions (Table 3) showed that the Soil X Heat interaction is significant for all depths, which makes it difficult to interpret the effect of heat treatment or soil differences. Individual planned comparisons (Table 3) show that for the dry moisture condition, WDPT's decreased with increasing heat treatment across all depths. The higher temperatures reduced water repellency to deeper depths. The ash-cap and mixed ash-cap soils, however, showed increasing WDPT's at the 50 to 70 -mm depths (Figs. 3 
and 4), although not shown WDPT increased to 90-mm depth, then decreased. This may be due to the fact that the temperatures were not high enough to reduce the preburn repellency. At the high heat treatment, hydrophobic substances may have condensed (DeBano, 1966; DeBano and Krammes, 1966) to depths below 70$\mathrm{mm}$, causing repellency even to the $90-\mathrm{mm}$ depth.

The individual planned comparisons for the wet moisture condition follows the pattern observed for the dry moisture condition except for the high heat treatment at the 30 and 50-mm depths. At these depths (Figs. 3, 5 and 6 and Table 3), WDPT's are significantly longer than for all other heat treatments. This heat treatment created slight to moderate repellency.

A one-way ANOVA for the dry, granitic soil (Fig. 6) showed that low heat maintained WDPT's observed in the unheated cores. This trend was also observed for the mixed ash-cap and no ash-cap soils. The WDPT was significantly longer for the low heat treatment than the other heat treatments at depths of 0,10 and 20-mm. Below 20-mm, the WDPT decreased rapidly for all heat treatments. Moderate and high heat treatments significantly reduced WDPT's to the point where slight to no repellency was observed. For the wet moisture condition, low heat increased WDPT at the surface. Moderate heat increased WDPT's at the 10 and 20-mm depths and high heat increased WDPT's at the 20 and 30-mm depths (Fig. 6), suggesting that heating redistributed hydrophobic substances (DeBano et al., 1970; DeBano, 1981) to depths that depended on the heat treatment, causing water repellency at these depths.

The results of the heat treatment effect for the wet moisture condition indicate that the low heat treatment of the wet ash-cap soil induced slight repellency near the surface and was not repellent at 30-mm, which corresponded to a large temperature drop (Figure 2). The moderate heat treatment was not repellent. The high heat treatment induced moderate repellency at depths of 30-mm (WDPT $68 \mathrm{~s}$ ). This same pattern also occurred for the granitic soil and no ash-cap soil at 50-mm depth. Savage (1974) indicated that a temperature of $250{ }^{\circ} \mathrm{C}$ was needed to fix the hydrophobic substances (i.e. coat the soil particles) after condensation.

Temperatures of $250{ }^{\circ} \mathrm{C}$ occurred at the 10-mm depth for the wet condition for the granitic and ash-cap soils and at 30-mm depth for the no ash-cap and mixed ash-cap soils (Fig. 2). The longest WDPT for granitic and ash-cap soils for the high heat, wet condition occurred at the 30-mm depth where temperatures were $80-100{ }^{\circ} \mathrm{C}$, whereas the no ash-cap and mixed ash-cap soils, these temperatures occurred at the 50-mm depth with corresponding longer WDPT. Therefore the temperatures needed to fix the hydrophobic substances may be less than $250{ }^{\circ} \mathrm{C}$ (Savage, 1974), especially for the wet conditions. 


\subsection{Soils}

The low heat treatment had the highest WDPT for the dry moisture condition (Table 3 and Figs. 3 to 6), therefore a one-way ANOVA was performed for all soils for the low heat treatment (Table 4). The granitic and mixed ash-cap soils had significantly higher WDPT's at the 10-mm depth. The mixed ash-cap soil had the longest WDPT at 20 and 70-mm depths, also the no ash-cap soil at the 30 and 50-mm depths.

The WDPTs of the four soils at their surfaces were not significantly different (Table 3). At the 10, 20, 30 and 50-mm depths for the wet moisture condition, the mixed ash-cap soil WDPT was significantly greater than the other three soils. One-way ANOVA's indicate that the WDPT were significantly greater for the ash-cap and granitic soils for the high heat treatment at the 30-mm depth (Figs. 3 and 6), and for the no ash-cap soil at the 50-mm depth (Fig. 5). This was probably due to water-soluble, hydrophobic substances being translocated down to lower depths where they cool, condense and coat soil particles (DeBano, 1966; DeBano and Krammes, 1966). Higher total $\mathrm{N}$ and total $\mathrm{C}$ in the mineral soil of the no ash-cap soil did not result in more or less repellency than for the other soils.

The granitic soil, with the smallest specific surface area (Table 1), did not produce the greatest WDPT. The mixed and no ash-cap soils had longer WDPT especially at deeper depths (Tables 3 and 4). Since the range of specific surface areas used in this study was small, no soil type effect was detected.

\subsection{Moisture Conditions}

A one-way ANOVA examined the effect of soil water content for all soils (Table 5). The longest WDPT's were for the low heat treatment for both the dry and wet moisture conditions. Within the low heat, dry moisture condition, WDPT's were greater for all depths and significantly greater for the 20, 30 and 50-mm depths. This indicated that dry moisture conditions, especially under the low heat treatment, did not provide enough heat to reduce the moderate repellency observed in the controls. At the high heat treatment, WDPT were greater for the wet than the dry moisture condition at the 20 to 50-mm depths. The damping effect of soil water on maximum temperatures with depth resulted in critical temperatures of $80-100{ }^{\circ} \mathrm{C}$ for condensation of hydrophobic substances at shallower depths for the wet soils, compared to the dry soils. In dry soils we would expect to reduce repellency to greater depths than in a wet soil given a similar heat treatment. In a situation where repellency is created by volatilizing hydrophobic substances, we would expect to see higher WDPT's at greater depths in dry soils than in wet soils. 


\subsection{Soil Profile Heating}

We compared observed temperatures and repellency by layer using the classification scheme of Dekker and Ritsema (1994) (Table 2). Since there were some missing data due to differential heating, only 21 of the 24 treatment combinations were analyzed. Our predictions were correct for 15 out of 21 ( 72 percent) cells (combinations) but not necessarily at the proper depths. Overall, our hypotheses were better for the wet soils (80 percent) than for the dry soils (64 percent). Also the granitic and no ash-cap soils ( 83 and 80 percent) were better predicted than the ash-cap and mixed ash-cap soils (60 and 60 percent). Where our hypotheses did not predict correctly, repellency was expected in four of these treatment combinations at the 30 and 50-mm depths, but no repellency was found. It is possible that high heating for long periods of time in the layers immediately above, exhausted the hydrophobic substances that would cause repellency.

The no ash-cap soil, which had significantly higher total $\mathrm{N}$ and total C (Table 1) than the other soils, was one of these cases. If the added total $\mathrm{N}$ and total $\mathrm{C}$ were to contribute to the amount of hydrophobic substances available to create repellency, we would have expected a greater likelihood of repellency in this case than for the other soils for the same treatment combination. In the dry mixed ash-cap soil under low heat treatment, repellency was expected in the upper 20-mm but occurred at all depths. This is possibly the result of repellency occurring in the soil prior to heating as evident from the control cores, and from the hydrophobic substances not being volatilized by low temperatures. The other combination not predicted correctly was the wet ash-cap soil under the moderate heat treatment. Repellency was expected at the 20 to 30-mm depths but only a slight increase was observed at the $70-\mathrm{mm}$ depth.

\section{Conclusions}

Two types of water repellency were observed under laboratory conditions with four northern Rocky Mountain forest soils. The first type occurred when the soils were very dry without heating and occurred throughout the soil profile although more often at shallow depths $(<20-\mathrm{mm})$. The second type occurred after heating. At typical wildfire soil profile temperatures and when the soil was dry, water repellency occurred at shallow depths $(<20-\mathrm{mm})$. With wet soils, i.e. conditions that commonly occur during prescribed fire, water repellency was less pronounced and occurred deeper in the soil profile. This occurred after long heating times, which under field conditions, would typically only occur during smoldering fires. Therefore water repellency after prescribed fire would probably be minimal.

The depth of the water repellency varied but was related to the temperature gradient, and appeared to be in the upper 10 to 20 -mm soil depths for dry soils. In wet soils, the temperature increase due to heating took 
longer and presumably the concentration of water vapors was greater and the hydrophobic substances may be concentrated by condensing in thinner layers in the soil profile (DeBano, 1966; DeBano and Krammes, 1966). Longer WDPT occurred at the 20 to 50-mm depths in wet soils where the soil temperatures did not reach $260{ }^{\circ} \mathrm{C}$. The increased repellency occurred presumably because hydrophobic substances cooled and condensed on the soil particles.

These results suggest that water repellency occurs in dry soils in the absence of fire but needs to be substantiated under field conditions. Also, there is interaction between fire induced heating, soil water content, and soil type. Of these, heating caused by burning of the forest floor caused the greatest effect on repellency. Heating of dry soil in the absence of naturally occurring repellency may result in water repellency in the mineral soil, which can contribute to reduced infiltration of water into the soil and increased erosion (Robichaud, 1996). Field observations of wildfire soil temperatures and corresponding WDPT are needed to evaluate reduced repellency with higher temperatures at shallow depths, and to evaluate temperature gradients to confirm observations with laboratory experiments. 


\section{References}

Albini, F., Amin, M.R., Hungerford, R.D., Frandsen, W.H., Ryan, K.C., 1996. Models for fire-driven heat and moisture transport in soils. Gen. Tech. Rep. INT-GTR-335. USDA For. Serv., Intermountain Res. Sta., Ogden, UT. 16 pp.

Campbell, G.S., Jungbauer, Jr., J.D., Bristow, K.L, Hungerford, R.D., 1995. Soil temperature and water content beneath a surface fire. Soil Sci. 159, 363-374.

Cooper, S.V., Neiman, K.E, Steele, R., Roberts, D.W., 1991. Forest habitat types of Northern Idaho: a second approximation. Gen. Tech. Rep. INT-GTR-236. USDA For. Serv., Intermountain Res. Sta., Ogden, UT. 143 pp.

DeBano, L.F., 1966. Formation of non-wettable soils . . involves heat transfer mechanism. Res. Note PSW-132. USDA For. Serv., Pacific Southwest For. Range Exp. Sta., Berkeley, CA. 8 pp.

DeBano, L.F., 1973. Water repellent soils: their implications in forestry. J. For. 71, 220-223.

DeBano, L.F., 1981. Water repellent soils: a state-of-the-art. Gen. Tech. Rep. PSW-46. USDA For. Serv., Pacific Southwest For. Range Exp. Sta., Berkeley, CA. 21 pp.

DeBano, L.F., Krammes, J.S., 1966. Water repellent soils and their relation to wildfire temperatures. Int. Assoc. Hydrol. Sci. 2,14-19.

DeBano, L.F., Osborn, J.F., Krammes, J.S. Letey, Jr., J., 1967. Soil wettability and wetting agents . . o our current knowledge of the problem. Gen. Tech. Rep. PSW-43. USDA For. Serv., Pacific Southwest For. Range Exp. Sta., Berkeley, CA. 13 pp.

DeBano. L.F., Mann, L.D., Hamilton, D.A., 1970. Translocation of hydrophobic substances into soil by burning organic litter. Soil Sci. Soc. Am. Proc. 34, 130-133.

DeBano, L.F., Savage, S.M., Hamilton D.A., 1976. The transfer of heat and hydrophobic substances during burning. Soil Sci. Soc. Am. J. 40, 779-782.

DeBano, L.F., Dunn, P.H., Conrad, C.E, 1977. Fire's effect on physical and chemical properties of chaparral soils. pp. 65-74. In Symposium on the environmental consequences of fire and fuel management in Mediterranean ecosystems. Proc., Palo Alto, CA. 15 Aug. 1977. Gen. Tech. Rpt. WO3. USDA For. Serv., Wash., DC. 498 pp.

DeBano, L.F., Neary, D.G., Ffolliott, P.F., 1998. Fire’s effect on ecosystems. John Wiley \& Sons, New York. 333 pp.

Dekker, L.W., Ritsema, C.J., 1994. How water moves in a water repellent sandy soil 1. potential and actual water repellency. Water Resour. Res. 30, 2507-2517.

Dunn, P.H., DeBano L.F., 1977. Fire's effect on biological and chemical properties of 
chaparral soils. pp.75-84. In: Symposium on the environmental consequences of fire and fuel management in Mediterranean ecosystems. Proc., Palo Alto, CA. 15 Aug.1977. Gen. Tech. Rpt. WO-3. USDA For. Serv., Wash., DC. 498 pp.

Giovannini, G., Lucchesi, S., 1983. Effects of fire on hydrophobic and cementing substances of soil aggregates. Soil Sci. 136, 231-235.

Hillel, D., 1982. Introduction to soil physics. Academic Press, San Diego, CA. 364 pp.

Hudson, R.A., Traina, S.J., Shane, W.S., 1994. Organic mater comparison of wettable and nonwettable soils from bentgrass sand greens. Soil Sci. Soc. Am. Proc. 58, 361-367.

Krammes, J.S., DeBano, L.F., 1965. Soil wettability: a neglected factor in watershed management. Water Resour. Res. 1, 283-286.

Letey, J., Osborn, J., Pelishek, R.E., 1962. Soil wettability as a factor in erodibility. Bull. Int. Assoc. Hydrol. Sci. 3, 75-81.

Milliken, G.A., Johnson, D.E., 1984. Analysis of messy data, vol. I: designed experiments. Lifetime Learning Publ., Belmont, CA. 473 pp.

Ott, L., 1988. An introduction to statistical methods and data analysis. PWS-Kent Publ., Boston, MA. 835 pp.

Robichaud, P.R., 1996. Spatially-varied erosion potential from harvested hillslopes after prescribed fire in the Interior Northwest. Ph.D. diss. Univ. of Idaho, Moscow. 219 pp.

Savage, S.M., 1974. Mechanism of fire-induced water repellency in soil. Soil Sci. Soc. Am. Proc. 38, 652-657.

Steele, R., Pfister, R.D., Ryker, R.A., Kittams, J.A., 1981. Forest habitat types of central Idaho. Gen. Tech. Rep. INTGTR-114. USDA For. Serv., Intermountain Res. Sta., Ogden, UT. 138 pp.

Topp, G.C., Davis, J.L., Annan, A.P., 1982. Electromagnetic determination of soil water content using TDR: I. applications to wetting fronts and steep gradients. Soil Sci. Soc. Proc. 46, 672-678.

Wells, C.G., Campbell, R.E. DeBano, L.F., Lewis, C.E., Fredricksen, R.L., Franklin, E.C., Froelich, R.C., Dunn. P.H., 1979. Effects of fire on soil: a state-of-knowledge review. Gen. Tech. Rep. WO-7. USDA For. Serv. Wash. DC. $34 \mathrm{pp}$. 
Table 1. Forest floor and 0 to 50-mm soil depth description for the soils used in the laboratory experiments.

\begin{tabular}{|c|c|c|c|c|c|c|c|c|c|c|c|c|}
\hline \multirow[b]{2}{*}{ Soil } & \multirow[b]{2}{*}{ Classification } & \multirow[b]{2}{*}{$\begin{array}{c}\text { Sand } \\
(\%)\end{array}$} & \multicolumn{7}{|c|}{ - } & \multicolumn{3}{|c|}{ - . - . - Forest floor - . . - - } \\
\hline & & & $\begin{array}{l}\text { Silt } \\
(\%)\end{array}$ & $\begin{array}{l}\text { Clay } \\
(\%)\end{array}$ & $\begin{array}{c}>2 \mathrm{~mm} \\
(\%)\end{array}$ & $\begin{array}{c}a_{s}^{\dagger} \\
\left(m^{2} g^{-1}\right)\end{array}$ & pH & $\begin{array}{c}\text { Total N } \\
\text { (\%) }\end{array}$ & $\begin{array}{c}\text { Total C } \\
\text { (\%) }\end{array}$ & $\begin{array}{l}\text { Depth } \\
(\mathrm{mm})\end{array}$ & $\begin{array}{c}\text { Total N } \\
\text { (\%) }\end{array}$ & $\begin{array}{c}\text { Total C } \\
(\%)\end{array}$ \\
\hline ash-cap & Typic Hapludand & 56 & 42 & 2 & 23 & 0.040 & 6.2 & $0.15 a^{\ddagger}$ & $4.16 \mathrm{ab}$ & $42.8 \mathrm{a}$ & $0.94 a$ & $37.7 \mathrm{a}$ \\
\hline mixed ash-cap & Andic Dystrocrept & 63 & 36 & 1 & 28 & 0.028 & 5.8 & $0.16 \mathrm{a}$ & $4.88 \mathrm{~b}$ & $31.5 \mathrm{a}$ & $0.82 \mathrm{a}$ & $32.1 \mathrm{a}$ \\
\hline no ash-cap & Typic Dystrocrept & 55 & 44 & 1 & 39 & 0.024 & 6.5 & $0.32 \mathrm{~b}$ & $7.08 \mathrm{c}$ & $33.2 \mathrm{a}$ & $0.90 \mathrm{a}$ & $26.8 \mathrm{a}$ \\
\hline granitic & Typic Cryorthent & 70 & 28 & 2 & 24 & 0.017 & 6.6 & $0.12 \mathrm{a}$ & $3.04 a$ & $29.2 \mathrm{a}$ & $1.06 \mathrm{a}$ & $35.2 \mathrm{a}$ \\
\hline
\end{tabular}

${ }^{\dagger}$ Specific surface area calculated by methods of Hillel (1982).

$\doteqdot$ Means followed by the same letter within a column are not significantly different by Fisher’s LSD method at the $\alpha=0.05$ level. 
Table 2. Comparison of water repellency among soils, moisture conditions and heat treatments using the classification developed by Dekker and Ritsema (1994).

\begin{tabular}{|c|c|c|c|c|c|}
\hline \multirow[b]{2}{*}{ Soil } & \multirow[b]{2}{*}{$\begin{array}{l}\text { Moisture } \\
\text { conditions }\end{array}$} & \multirow[b]{2}{*}{ Control } & \multicolumn{3}{|c|}{ Heat treatments $\left({ }^{\circ} \mathrm{C}\right)$} \\
\hline & & & $\begin{array}{c}\text { Low } \\
\text { 100-150 }\end{array}$ & $\begin{array}{c}\text { Moderate } \\
250-300\end{array}$ & $\begin{array}{c}\text { High } \\
400-500\end{array}$ \\
\hline \multirow[t]{2}{*}{ ash-cap } & dry & $\mathrm{SR}^{\dagger}$ & $\mathrm{m}^{\ddagger}$ & $\mathrm{N}$ & $\mathrm{N}$ \\
\hline & wet & SR & SR & $\mathrm{N}$ & SR \\
\hline \multirow[t]{2}{*}{ mixed ash-cap } & dry & SR & MR & SR & $\mathrm{N}$ \\
\hline & wet & MR & SR & $\mathrm{m}$ & $\mathrm{N}$ \\
\hline \multirow[t]{2}{*}{ no ash-cap } & dry & MR & SR & SR & $\mathrm{N}$ \\
\hline & wet & $\mathrm{N}$ & SR & $\mathrm{m}$ & SR \\
\hline \multirow[t]{2}{*}{ granitic } & dry & SR & SR & SR & SR \\
\hline & wet & $\mathrm{N}$ & SR & SR & SR \\
\hline
\end{tabular}

${ }^{\dagger} \mathrm{N}$ denotes non repellent conditions with WDPT less than $5 \mathrm{~s}$.

SR denotes slightly repellent conditions with WDPT between 5 and $60 \mathrm{~s}$.

MR denotes moderately repellent conditions with WDPT greater than $60 \mathrm{~s}$.

The mean WDPT from the 10, 20 and 30-mm depths were used.

$\ddagger$ m denotes missing values. Missing cells resulted from differential heating from one side of the core to the other, necessitating removal of the core from the analysis. 
17

Table 3. Probability values and water drop penetration times for the two-way ANOVA of the dry and wet moisture conditions for all soils and heat treatments.

\begin{tabular}{|c|c|c|c|c|c|c|c|c|c|c|c|c|}
\hline \multirow[t]{2}{*}{ Depth (mm) } & \multicolumn{2}{|c|}{0} & \multicolumn{2}{|c|}{10} & \multicolumn{2}{|c|}{20} & \multicolumn{2}{|c|}{30} & \multicolumn{2}{|c|}{50} & \multicolumn{2}{|c|}{70} \\
\hline & dry & wet & dry & wet & dry & wet & dry & wet & dry & wet & dry & wet \\
\hline Soil & 0.6 & 0.8 & 0.2 & $0.0008^{*}$ & $0.004^{*}$ & $0.01^{*}$ & $0.02^{*}$ & $0.002^{*}$ & $0.02^{*}$ & $0.0001^{*}$ & $0.0001^{*}$ & 0.07 \\
\hline Heat & $0.01^{*}$ & 0.07 & $0.00001^{*}$ & $0.006^{*}$ & $0.00001^{*}$ & 0.7 & $0.03^{*}$ & $0.004^{*}$ & $0.04^{*}$ & $0.0009^{*}$ & $0.04^{*}$ & 0.7 \\
\hline Soil X Heat & $0.00003^{*}$ & $0.003^{*}$ & $0.00001^{*}$ & $0.00001^{*}$ & $0.001^{*}$ & $0.00001^{*}$ & $0.00006^{*}$ & $0.00001^{*}$ & $0.00001^{*}$ & $0.00001^{*}$ & $0.00004^{*}$ & $0.02^{*}$ \\
\hline Soil & & & & & & & $\Gamma(s)$ & & & & & \\
\hline ash-cap & 20.4 & 42.0 & 21.6 & $10.8 \mathrm{a}^{\dagger}$ & $17.2 \mathrm{a}^{\dagger}$ & $11.7 \mathrm{a}$ & $7.6 \mathrm{a}$ & $20.9 a$ & $12.3 a$ & $13.0 \mathrm{a}$ & $12.2 \mathrm{a}$ & 5.9 \\
\hline mixed ash-cap & 22.7 & 26.7 & 40.7 & $71.4 \mathrm{~b}$ & $41.2 \mathrm{~b}$ & $54.1 \mathrm{~b}$ & $47.9 \mathrm{~b}$ & $39.2 \mathrm{~b}$ & $38.5 b$ & $32.1 \mathrm{~b}$ & $63.1 b$ & 14.6 \\
\hline no ash-cap & 32.2 & 20.0 & 44.5 & $11.7 \mathrm{a}$ & $54.9 \mathrm{~b}$ & $18.6 \mathrm{a}$ & $37.6 \mathrm{~b}$ & $3.9 \mathrm{c}$ & $23.8 \mathrm{~b}$ & $10.3 a$ & $8.5 a$ & 1.9 \\
\hline granitic & 39.5 & 19.9 & 44.3 & $15.3 a$ & $28.5 \mathrm{ab}$ & $31.7 \mathrm{c}$ & $11.0 \mathrm{a}$ & $19.4 a$ & $6.4 \mathrm{ac}$ & $9.0 \mathrm{a}$ & $4.7 \mathrm{a}$ & 0.2 \\
\hline Heat & & & & & & & & & & & & \\
\hline control & $56.1 \mathrm{a}$ & 42.7 & $79.5 \mathrm{a}$ & $40.6 \mathrm{a}$ & $66.1 \mathrm{a}$ & 37.6 & $32.4 a$ & $26.1 \mathrm{a}$ & $31.3 a$ & $20.9 a$ & $40.7 \mathrm{a}$ & 9.3 \\
\hline low & $49.1 \mathrm{a}$ & 52.7 & $63.9 \mathrm{a}$ & $36.9 \mathrm{a}$ & $61.5 a$ & 23.8 & $54.3 \mathrm{ab}$ & $8.0 \mathrm{~b}$ & $31.6 a$ & $5.1 \mathrm{~b}$ & $12.5 \mathrm{~b}$ & 5.7 \\
\hline moderate & $17.4 \mathrm{~b}$ & 0.4 & $17.4 a b$ & $19.2 \mathrm{a}$ & $22.6 \mathrm{~b}$ & 21.5 & $25.6 \mathrm{ac}$ & $9.3 \mathrm{~b}$ & $17.8 \mathrm{a}$ & $5.8 \mathrm{~b}$ & $22.5 b$ & 4.9 \\
\hline high & $3.6 \mathrm{~b}$ & 1.4 & $0.4 \mathrm{~b}$ & $1.3 \mathrm{~b}$ & $2.7 \mathrm{~b}$ & 22.9 & $3.3 \mathrm{c}$ & $33.9 \mathrm{a}$ & $5.1 \mathrm{~b}$ & $24.9 \mathrm{a}$ & $12.8 \mathrm{~b}$ & 2.5 \\
\hline
\end{tabular}

Probability values are significant at the $\alpha=0.05$ level. 
Means followed by the same letter within a column are not significantly different by Fisher's LSD method at the $\alpha=0.05$ level. 
Table 4. Probability values and water drop penetration times for the one-way ANOVA of the dry moisture condition at low heat treatment for all soils.

\begin{tabular}{|c|c|c|c|c|c|c|}
\hline Depth (mm) & 0 & 10 & 20 & 30 & 50 & 70 \\
\hline Soil & 0.9 & $0.02^{*}$ & $0.0009^{*}$ & $0.01^{*}$ & $0.01^{*}$ & $0.007^{*}$ \\
\hline & & & WDPT (s) & & & \\
\hline ash-cap & $\mathrm{m}^{\dagger}$ & $\mathrm{m}$ & $\mathrm{m}$ & $\mathrm{m}$ & $\mathrm{m}$ & $\mathrm{m}$ \\
\hline mixed ash-cap & 13.0 & $78.9 \mathrm{a}^{\ddagger}$ & $81.5 \mathrm{a}$ & $51.0 \mathrm{a}$ & $44.5 \mathrm{a}$ & $35.5 a$ \\
\hline no ash-cap & 51.6 & $32.6 \mathrm{~b}$ & $45.5 b$ & $102.3 \mathrm{~b}$ & $49.9 \mathrm{a}$ & $1.7 \mathrm{~b}$ \\
\hline granitic & 85.2 & $80.4 a$ & $57.3 \mathrm{c}$ & $9.7 \mathrm{c}$ & $0.5 \mathrm{~b}$ & $0.3 \mathrm{~b}$ \\
\hline
\end{tabular}

Probability values are significant at the $\alpha=0.05$ level.

${ }^{\dagger} \mathrm{m}$ denotes missing values. Missing cells resulted from differential heating from one side of the core to the other, necessitating removal of the core from the analysis.

$\doteqdot$ Means followed by the same letter within a column are not significantly different by Fisher's LSD method at the $\alpha=0.05$ level. 
Table 5

Probability values and water drop penetration times for the one-way ANOVA of the moisture conditions for all soils at three heat treatments

\begin{tabular}{|c|c|c|c|c|c|c|}
\hline Depth (mm) & 0 & 10 & 20 & 30 & 50 & 70 \\
\hline \multicolumn{7}{|l|}{ Low heat } \\
\hline $\begin{array}{l}\text { Moisture condition } \\
W D P T(s)\end{array}$ & 0.7 & 0.06 & $0.005^{\mathrm{a}}$ & $0.004^{\mathrm{a}}$ & $0.02^{\mathrm{a}}$ & 0.6 \\
\hline Dry & 61.1 & 60.4 & $56.1 \mathrm{a}^{\mathrm{b}}$ & $34.7 \mathrm{a}$ & $23.8 \mathrm{a}$ & 9.5 \\
\hline Wet & 50.4 & 40.1 & $24.1 b$ & $7.1 \mathrm{~b}$ & $4.8 \mathrm{~b}$ & 4.4 \\
\hline \multicolumn{7}{|l|}{ Moderate heat } \\
\hline $\begin{array}{l}\text { Moisture condition } \\
W D P T(s)\end{array}$ & 0.2 & 0.4 & 0.6 & 0.09 & 0.3 & 0.1 \\
\hline Dry & 17.9 & 17.8 & 28.6 & 29.8 & 18.7 & 20.3 \\
\hline Wet & 0.3 & 29.5 & 33.4 & 11.1 & 8.1 & 2.2 \\
\hline High heat & & & & & & \\
\hline $\begin{array}{l}\text { Moisture condition } \\
W D P T(s)\end{array}$ & 0.4 & 0.6 & $0.02^{\mathrm{a}}$ & 0.1 & $0.04^{\mathrm{a}}$ & 0.2 \\
\hline Dry & 4.7 & 0.3 & $3.0 \mathrm{a}$ & 4.2 & $3.6 \mathrm{a}$ & 7.8 \\
\hline Wet & 1.1 & 0.4 & $16.9 \mathrm{~b}$ & 17.6 & $15.0 \mathrm{~b}$ & 2.5 \\
\hline
\end{tabular}

${ }^{a}$ Probability values are significant at the $\alpha=0.05$ level.

${ }^{\mathrm{b}}$ Means followed by the same letter within a column are not significantly different by Fisher's LSD method at the $\alpha=0.05$ level. 
P.R. Robichaud, R.D. Hungerford / Joumal of Hydrology 231-232 (2000) 207-2l9

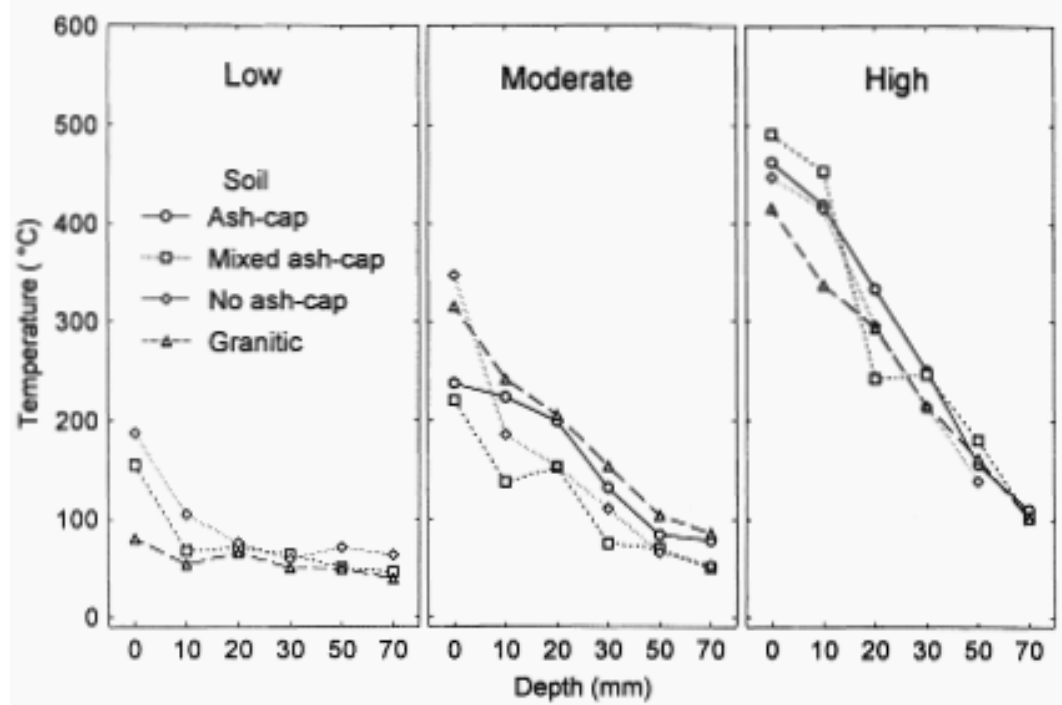

Fig. 1 Measured temperatures at each heat treatment used to assign soil cores for the dry moisture condition.

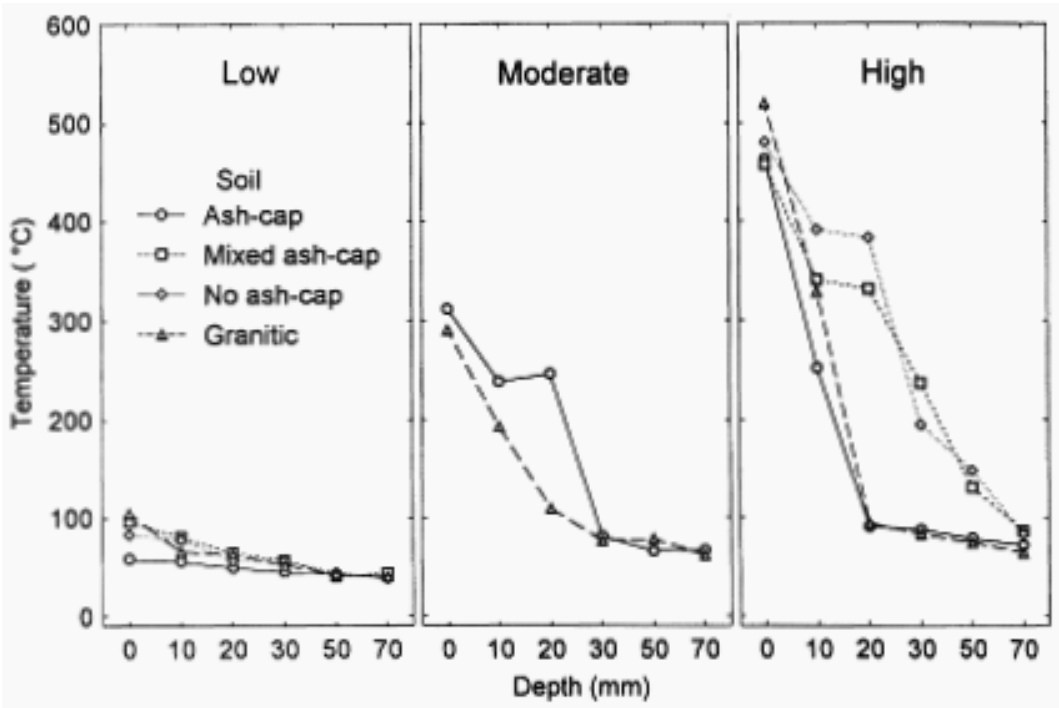

Fig. 2. Measured temperatures at each heat treatment used to assign soil cores for the wet moisture condition. 


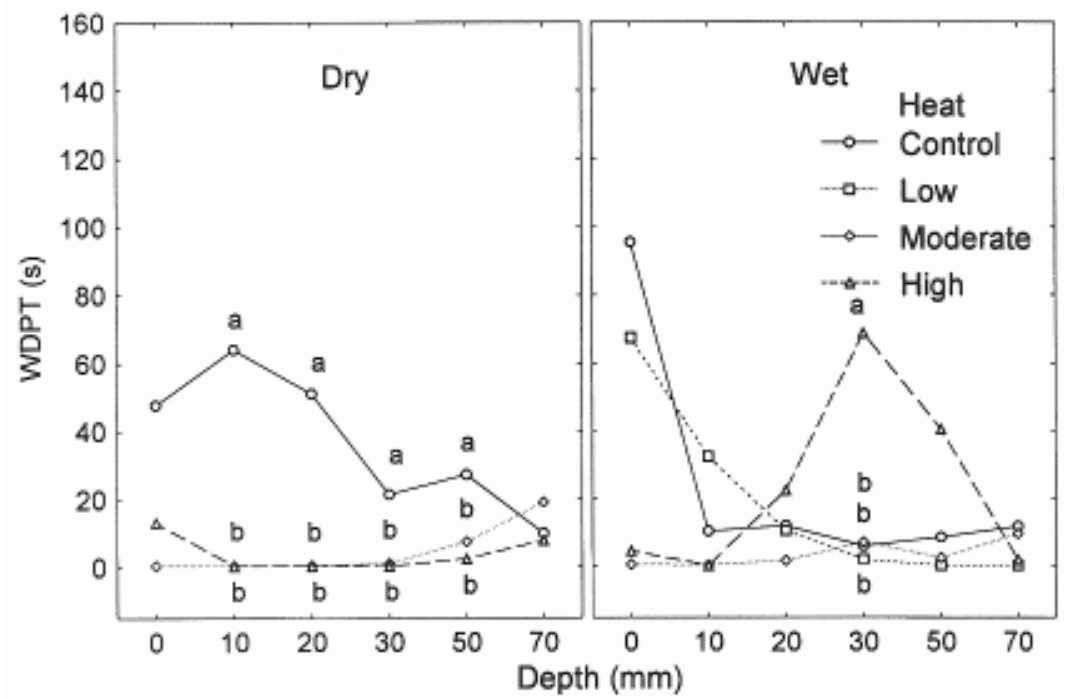

Fig. 3. Water drop penetration times for the ash-cap soil at various depths for dry and wet moisture conditions. Means for each heat treatment followed by the same letter by depth, are not significantly different by Fisher's LSD method at the $\mathrm{a}=0.05$ level.

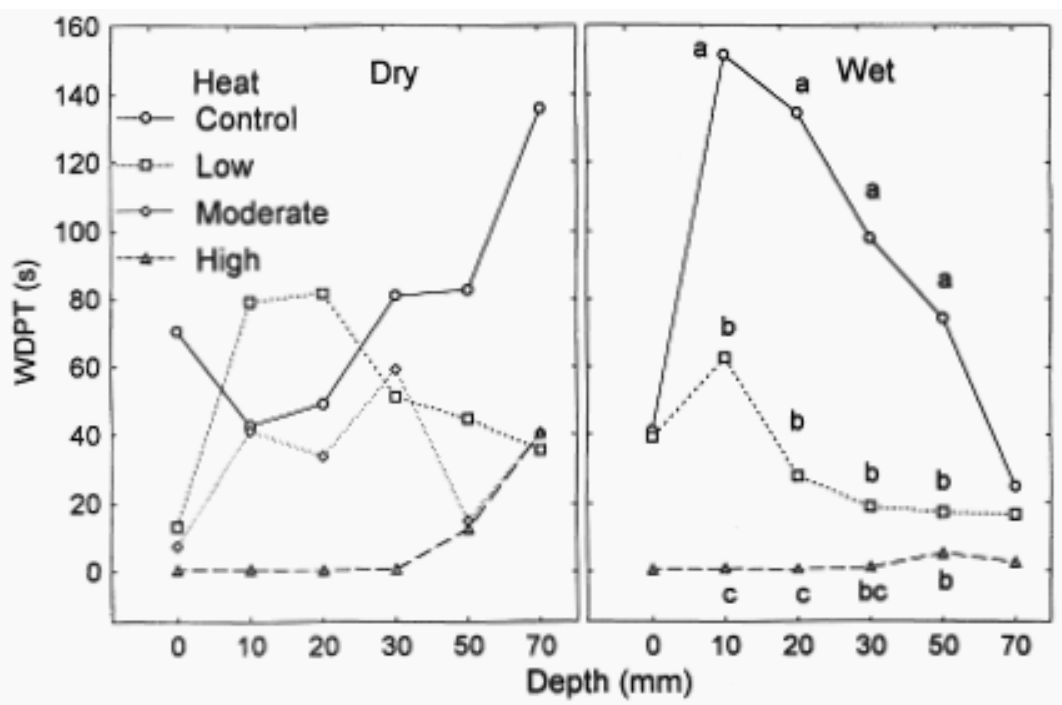

Fig. 4. Water drop penetration times for the mixed ash-cap soil at various depths for the dry and wet moisture conditions. Means for each heat treatment followed by the same letter by depth, are not significantly different by Fisher's LSD method at the $\mathrm{a}=0.05$ level.

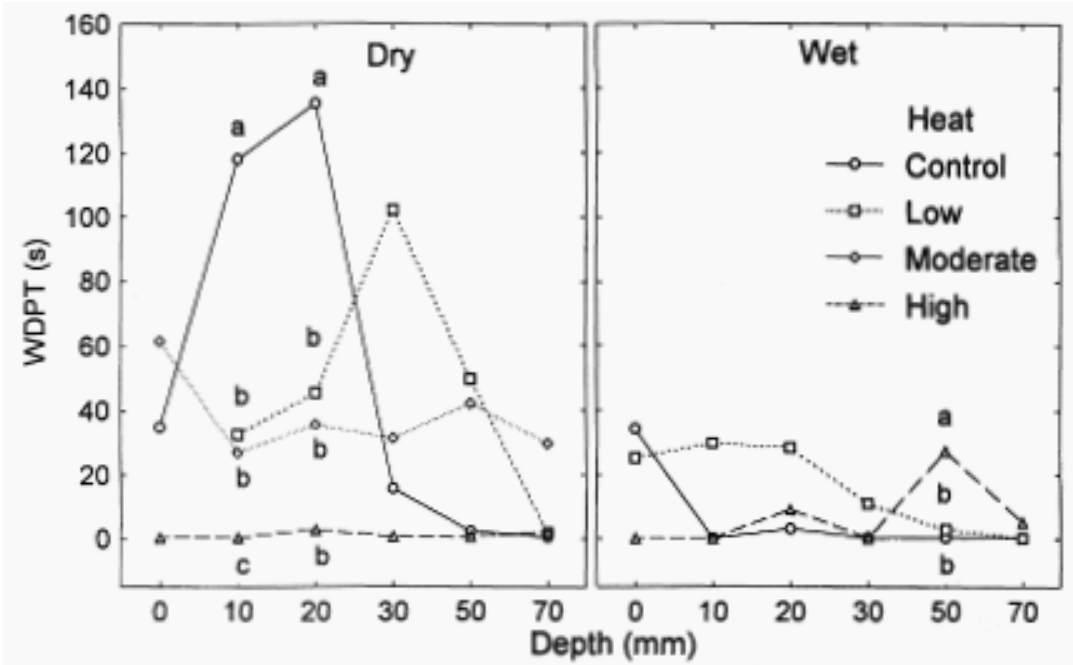

Fig. 5. Water drop penetration times for the no ash-cap soil at various depths for the dry and wet moisture conditions. Means for each heat treatment followed by the same letter by depth, are not significantly different by Fisher's LSD method at the $\mathrm{a}=0.05$ level. 


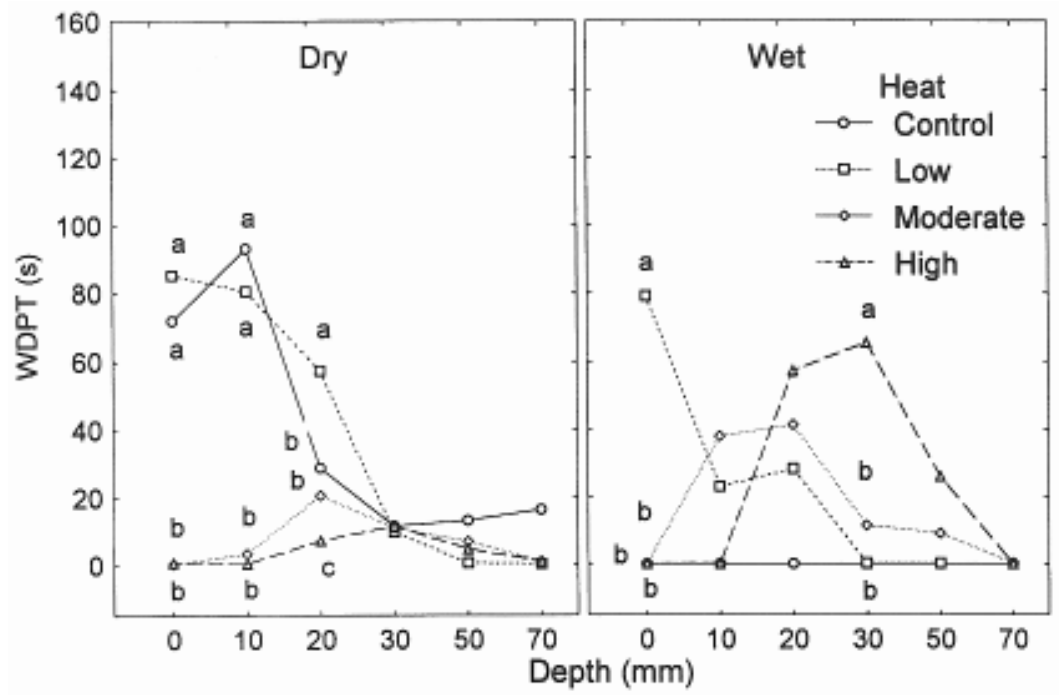

Fig. 6. Water drop penetration times for the granitic soil at various depths for dry and wet moisture conditions. Means for each heat treatment followed by the same letter by depth, are not significantly different by Fisher's LSD method at the $\mathrm{a}=0.05$ level. 


\section{Rocky Mountain}

This paper was published as:

Robichaud, P. R.; Hungerford, R. D. 2000. Water repellency by laboratory

burning of four northern Rocky Mountain forest soils.Journal of Hydrology. 231-232(2000): 207-219.

Keywords: hydrophobicity, soil heating, water drop penetration time, water repellent

$2000 f$

Moscow Forestry Sciences Laboratory

Rocky Mountain Research Station

USDA Forest Service

1221 South Main Street

Moscow, ID 83843

http://forest.moscowfsl.wsu.edu/engr/ 